\title{
Kinetic Study of the Electrochemical Oxidation of Methylene Blue with Pt Electrode
}

\author{
M.A. El Hajj Hassan and M.M. El Jamal* \\ Lebanese University, Faculty of Sciences (I), Chemistry Department, El Hadath, Lebanon
}

Received 21 October 2012; accepted 31 October 2012

\begin{abstract}
Kinetic study of the indirect oxidation of methylene blue on Pt electrode in presence of several strong electrolytes is undertaken. Different operating conditions that affected the treatment process were studied in order to find the best conditions. The order with respect to methylene blue is zero order in presence of chloride, but it is second order in presence of bromide. The oxidation rate was affected by current density, halide concentration $(\mathrm{KCl}, \mathrm{KBr})$, nature of supporting electrolyte and initial $\mathrm{pH}$. However, the initial dye concentration and temperature did not show a significant effect. The oxidation of methylene blue in presence of iodide, fluoride and sulfate is absent, but it is important in presence of chloride and bromide. The product of the indirect oxidation is the chloronated (bromonated) methylene violet bernthsen.
\end{abstract}

Keywords: Pt electrode, indirect oxidation, methylene blue, effect of supporting electrolyte.

\section{Introduction}

Methylene Blue $\left(\mathrm{MB}^{+}\right)$has many uses in a range of different fields such as biology and chemistry. Photosensitizer for singlet oxygen generation, antioxidant and antiseptic, stain for fixed and living tissues, antidote to cyanide and nitrate poisoning [1]. $\mathrm{MB}^{+}$is used as optical oxygen sensors in the food industry $[1,2]$. It is an organic dye usually used to dye cotton, wool, acrylic, and silk. When it is used recklessly, it can cause serious illness such as vomiting, hard breathing, mental disorder and sweating. Different methods are being developed to carry out the elimination of toxic compounds from wastewater [3, 4]. These include biological and physicochemical methods such as flocculation combined with flotation, adsorption, membrane filtration, coagulation, and ion exchange. The literature is rich in articles about the kinetic studies of the reduction and oxidation of $\mathrm{MB}^{+}$chemically [5-8].

\footnotetext{
* Corresponding author. E-mail: mjamal@ul.edu.lb
} 
In recent years, electrochemical technologies have caused great interest because they offer effective means to solve environmental problems related to industrial processes and are more adaptable to a wide range of dye wastewaters [9-12]. Electrochemical treatment of textile wastewater with a high chloride concentration employing $\mathrm{Ti} / \mathrm{RuO}_{2}, \mathrm{Ti} / \mathrm{Pt}$ and $\mathrm{Ti} / \mathrm{Pt} / \mathrm{Ir}$ electrodes was investigated by Polacro et al. [13]. Electrochemical methods for wastewater treatment mainly involve the direct and indirect electrochemical oxidation [14]. By indirect electrolysis, organic pollutants can be degraded by generating in situ strong oxidative intermediates that convert these pollutants into less hazardous products $[15,16]$. The main oxidizing agents are active chlorine compounds, such as gaseous chlorine, hypochlorous acid, which are produced from original chlorides present in the wastewater [17]. The chemical and physical properties of chlorine in function of temperature, such as solubility and viscosity, are well studied [18]. Chlorine can electrochemically oxidize organic molecules quickly and irreversibly due to its intense oxidative activity. However, gaseous chlorine and hypochlorous acid can be easily interacted with organic molecules to form carcinogenic halogen compounds [19,20].

The efficiency of electrochemical oxidation is a function of electrode materials and supporting medium [14,17,19]. A brief review about the use of Boron Doped Diamond (BDD) in electrochemical oxidation provides total mineralization with high current efficiency of different organic molecules in real wastewaters [21].

The experimental results have indicated that the efficiency of electrochemical oxidation in chloride-mediated wastewaters is higher than that in chloride-free wastewaters for most of the electrodes [14]. The indirect oxidation of $\left(\mathrm{MB}^{+}\right)$ using chloride resistant mixed oxide metal occurs by replacement of one of dimetylamino groups by oxygen accompanied by chlorination of the aromatic rings [19]. However, using other electrodes such as $\mathrm{BDD}, \mathrm{PbO}_{2} / \mathrm{TiO}_{2}$ and $\mathrm{TiRuO}_{2} / \mathrm{Ti}$ oxide leads to total mineralization and decolorization of $\mathrm{MB}^{+}$solution $[14,17,22]$.

Therefore, in this work, a full kinetic study of the indirect oxidation of methylene blue using platinum anode in the presence of different supporting electrolytes was undertaken to know the product of the reaction in such conditions and to find the best conditions of the $\mathrm{MB}^{+}$oxidation.

\section{Experimental}

All chemical reagents used were of analytical grade. Methylene blue $\left(\mathrm{MB}^{+} \mathrm{Cl}^{-}\right)$is used as purchased from $\mathrm{BDH}\left(82 \%, \mathrm{C}_{16} \mathrm{H}_{18} \mathrm{~N}_{3} \mathrm{SCl}, \mathrm{MW}: 319.85 \mathrm{~g}\right)$. Stock solution of $\mathrm{MB}^{+}$was prepared by dissolving $100 \mathrm{mg}$ in one liter of distilled water. The most electrolysis experiments are done at room temperature $(293 \mathrm{~K})$, in presence of $10 \mathrm{mg} \mathrm{L}^{-1} \mathrm{MB}^{+}, 0.1 \mathrm{M} \mathrm{KX}$ (supporting electrolyte), where $\mathrm{X}$ is $\mathrm{Cl}^{-}, \mathrm{Br}^{-}$, with $10 \mathrm{~mA}$, at $\mathrm{pH}$ 2. The experiments were carried out in a single combined electrolytic cell. The electrolysis is performed on $100 \mathrm{~mL}$ solution prepared by mixing $10 \mathrm{~mL}$ of $100 \mathrm{mg} \mathrm{L}^{-1}$ of $\mathrm{MB}^{+}, 10 \mathrm{~mL}$ of $0.1 \mathrm{M} \mathrm{H}_{2} \mathrm{SO}_{4}, 10 \mathrm{~mL}$ of $1 \mathrm{M}$ halide salt and $70 \mathrm{~mL} \mathrm{H}_{2} \mathrm{O}$. 
The cover of the cell is designed to hold multiple electrodes. The anode and the cathode are Pt wire from Taccusel. Each electrode measured $1.2 \mathrm{~cm}$ length and $0.15 \mathrm{~cm}$ diameter. The distance between the two electrodes was $5 \mathrm{~cm}$. The electrolysis is done with a Chrono-Amperostat, type CEAMD-6, from Taccusel. The rate of the indirect oxidation of $\mathrm{MB}^{+}$was followed by measuring the absorbance at $662 \mathrm{~nm}$ (max. Wavelength of $\mathrm{MB}^{+}$). Absorption spectra were recorded on a double beam UV- Vis Specord 200 spectrometer, Analytic Jena AG (Germany). Measurements of $\mathrm{pH}$ were carried out using a Schott Gerate CG $819 \mathrm{pH}$-meter.

In order to determine the effect of the experimental parameters on the observed rate constant $\left(\mathrm{K}_{\mathrm{obs}}\right)$ and the order with respect to $\mathrm{MB}^{+}$, the absorbance $(\mathrm{A})$ of the solution was recorded after a predetermined time of electrolysis, during 10 minutes at $662 \mathrm{~nm}$. The plot of A, Ln A and 1/A vs. time allows to determine the best order.

The indirect oxidation of $\mathrm{MB}^{+}$was studied in function of several parameters such as initial $\mathrm{pH}$ (addition of diluted solutions of $\mathrm{H}_{2} \mathrm{SO}_{4}$ or $\mathrm{NaOH}$ ), nature of electrolyte, concentration of $\mathrm{MB}^{+}$, temperature, current, and ionic force. Electrochemical oxidation efficiency of $\mathrm{MB}^{+}$was determined in the presence of several strong electrolytes such as $\mathrm{Na}_{2} \mathrm{SO}_{4}, \mathrm{NaF}, \mathrm{KCl}, \mathrm{KBr}, \mathrm{KI}$. No variation of $\mathrm{pH}$ occurred during the experiments.

(a)

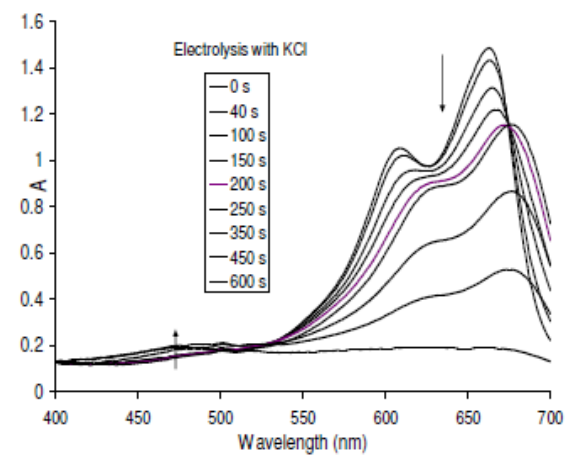

(b)

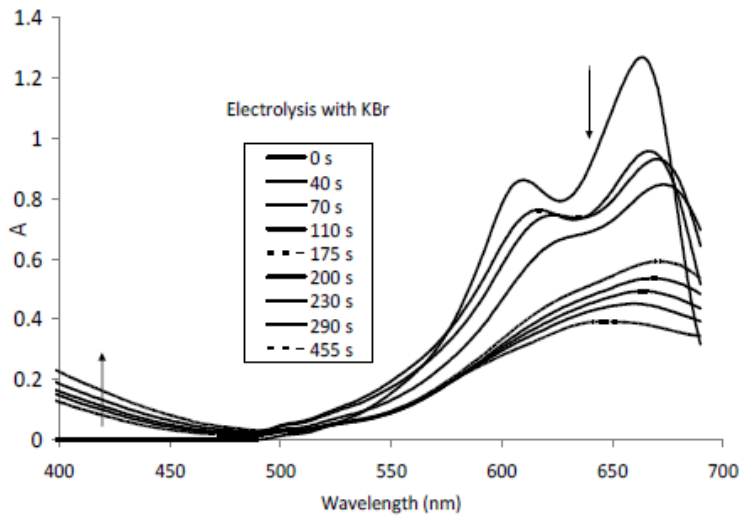

Figure 1. Variation of the visible spectrum of $\mathrm{MB}^{+}$as a function of electrolysis time in presence of $\mathrm{KCl}$ (Fig. 1a) and in presence of $\mathrm{KBr}$ (Fig.1b). $\left(10 \mathrm{mg} \mathrm{L}^{-1}\right.$ of $\mathrm{MB}^{+}, 0.1 \mathrm{M}$ KX, 10 mA, pH:2, T: 293 K).

\section{Results and discussions}

\section{Visible spectroscopy analysis}

The indirect oxidation of $\mathrm{MB}^{+}$at several initial $\mathrm{pH}$ (2 and 8) in presence of $\mathrm{Na}_{2} \mathrm{SO}_{4}$ is absent, but it occurred with high efficiency in presence of chloride (or bromide) (Fig. 1a, 1b). The variation of the visible spectrum with electrolysis time showed i) a decrease in the absorbance at $662 \mathrm{~nm}$ and a slight increase in the absorbance in the region between 450 and $500 \mathrm{~nm}$, ii) a shift in $\lambda_{\max }$ from 662 $\mathrm{nm}$ to $676 \mathrm{~nm}$ in the first step, then the absorbance continued decreasing with 
time without any shift in $\lambda_{\max }$. The presence of an isobestic point at $676 \mathrm{~nm}$ and the shift in $\lambda_{\max }$, prove the chlorination of the aromatic ring [23, 24].

Finally, the $\mathrm{MB}^{+}$solution became darker with the appearance of tiny black particles in solution. The addition of $\mathrm{CH}_{2} \mathrm{Cl}_{2}$ or toluene to the aqueous solution let it clear and turns the organic phase pink $\left(\lambda_{\max }: 544 \mathrm{~nm}\right)$ (Fig. 2).

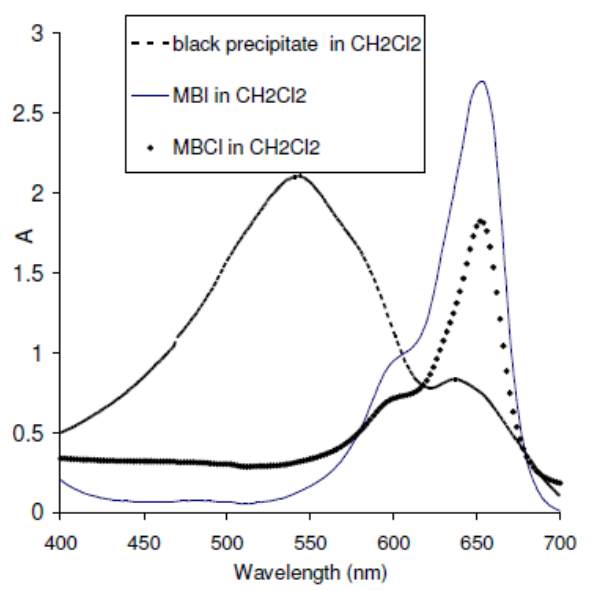

Figure 2. Spectrum of $\mathrm{MB}^{+} \mathrm{Cl}^{-}(\diamond), \mathrm{MB}^{+} \mathrm{I}^{-}(-)$and the precipitate obtained after electrolysis with $\mathrm{KCl}(--)$. (10 $\mathrm{mg} \mathrm{L}^{-1}$ of $\left.\mathrm{MB}^{+}, 0.1 \mathrm{M} \mathrm{KCl}, 10 \mathrm{~mA}, \mathrm{pH}: 2, \mathrm{~T}: 293 \mathrm{~K}\right)$.

Probably the tiny black particles correspond to the chlorinated methylene violet bernthsen $\left(\mathrm{MVBCl}_{2}\right)$ soluble in organic solvent but insoluble in water (uncharged compound) (Fig. 3) [25]. The indirect oxidation of $\mathrm{MB}^{+}$leads to the replacement of one dimethylamino groups of $\mathrm{MB}^{+}$with oxygen (Fig. 3). MVB is also the main product of the nucleophile attack of $\mathrm{MB}^{+}$by $\mathrm{OH}^{-}[26,27]$. The addition of acetone at the end the of electrolysis dissolves the dark precipitate and returns the slight black solution blue $\left(\lambda_{\max }: 610 \mathrm{~nm}\right)$. Probably redox reaction occurred between the electrolysis product and acetone.<smiles>CN(C)c1ccc2nc3ccc(=N)cc-3sc2c1</smiles>

$\oplus$<smiles>Cc1c(N(C)C)ccc2nc3ccc(=O)cc-3sc12</smiles>

Figure 3. Chemical structures of $\mathrm{MB}^{+}$and MVB.

The proposed mechanism is in line with that proposed by Donaldson et al. who confirmed by several techniques (XR and LC-MS) the formation of $\mathrm{C}_{10} \mathrm{H}_{10} \mathrm{Cl}_{2} \mathrm{~N}_{2} \mathrm{OS}\left(\mathrm{MVBCl}_{2}\right)$ during the anodic oxidation of $\mathrm{MB}^{+}$[19]. In the present case, the indirect oxidation of $\mathrm{MB}^{+}$did not lead to total mineralization of $\mathrm{MB}^{+}$as in the case with modified $\mathrm{TiO}_{2}$ electrode [22], and $\mathrm{TiRuO}_{2}$ [17], but it produces other toxic compounds.

\section{Kinetic Study}

The order with respect to $\mathrm{MB}^{+}$is done in presence of a large excess of $(\mathrm{KCl})$, source of chlorine compounds. The rate of the reaction can be expressed as: 


$$
\frac{-d\left[M B^{+}\right]}{d t}=-k\left[C l_{2}\right]^{\beta}\left[M B^{+}\right]^{\alpha}=-k_{o b s}\left[M B^{+}\right]^{\alpha}
$$

The plots of A (zero order), Ln A ( $1^{\text {st }}$ order) and 1/A ( $2^{\text {nd }}$ order $)$ vs. time allow to determine the order according to the best $\mathrm{R}^{2}$ value. The experimental data are well fitted to zero-order (Fig. 4). The oxidation at different concentrations of $\mathrm{MB}^{+}$follows the same behavior and the slope of the line A vs. time remains approximately constant, so the order with respect to $\mathrm{MB}^{+}$is zero, which means that the velocity of the reaction is independent of $\mathrm{MB}^{+}$concentration.

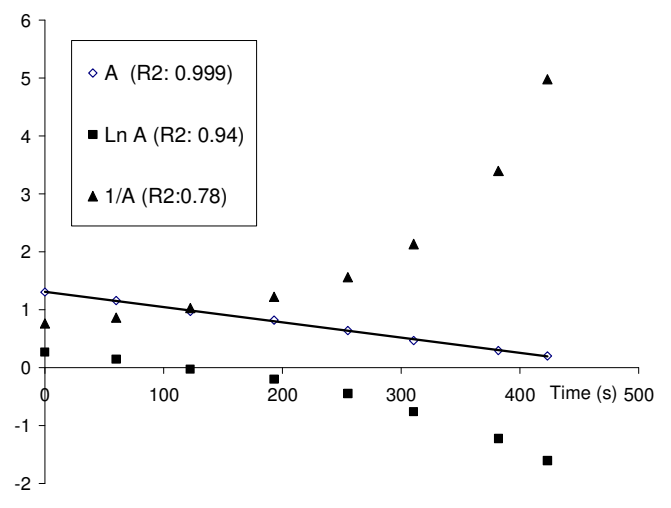

Figure 4. Order of the oxidation of $\mathrm{MB}^{+}$by generated chlorine compounds. $\left(10 \mathrm{mg} \mathrm{L}^{-1}\right.$ $\left.\mathrm{MB}^{+}, 0.1 \mathrm{M} \mathrm{KCl}, 10 \mathrm{~mA}, \mathrm{pH}: 1, \mathrm{~T}: 293^{\circ} \mathrm{C}\right)$.

\section{Effect of strong electrolyte}

The effect of the type of conductive electrolyte used in the electro degradation of toxic compounds affects strongly the efficiency of the process [22, 28]. The chloride salts give the best results since chloride plays in fact two roles: as strong electrolyte and as oxidant [29, 30]. It is interesting to study the effect of the nature of the strong electrolyte added on the oxidation rate. The electrolysis is done in presence of $0.1 \mathrm{M}$ of the following supporting electrolytes: $\mathrm{Na}_{2} \mathrm{SO}_{4}, \mathrm{NaF}$, $\mathrm{KCl}, \mathrm{KBr}$ and $\mathrm{KI}$ (added separately). The results show that the decolorization in presence of $\mathrm{Na}_{2} \mathrm{SO}_{4}$ and $\mathrm{NaF}$ is absent. These results are expected since $\mathrm{Na}_{2} \mathrm{SO}_{4}$ and $\mathrm{NaF}$ are non-electro active in the conditions of the experiment, and confirm the absence of the direct oxidation of $\mathrm{MB}^{+}$on Pt electrode.

The addition of $\mathrm{KI}$ to $\mathrm{MB}^{+}$solution provokes directly its precipitation. The discoloration of $\mathrm{MB}^{+}$solution is proportional to the volume of $1 \mathrm{M} \mathrm{KI}$ added, accompanied by the formation of a violet precipitate $\left(\mathrm{MB}^{+} \mathrm{I}^{-}\right)$. The dissolution of the obtained precipitate in $\mathrm{CH}_{2} \mathrm{Cl}_{2}$ gives light blue solution and has the same visible spectrum as $\mathrm{MB}^{+} \mathrm{Cl}^{-}$in $\mathrm{CH}_{2} \mathrm{Cl}_{2}$ with $\lambda_{\text {max }}$ at $652 \mathrm{~nm}$ (Fig. 3). The FTIR of the violet precipitate is similar to that of $\mathrm{MB}^{+} \mathrm{Cl}^{-}$. In this case the electro oxidation of $\mathrm{MB}^{+}$can not be done. 
(a)

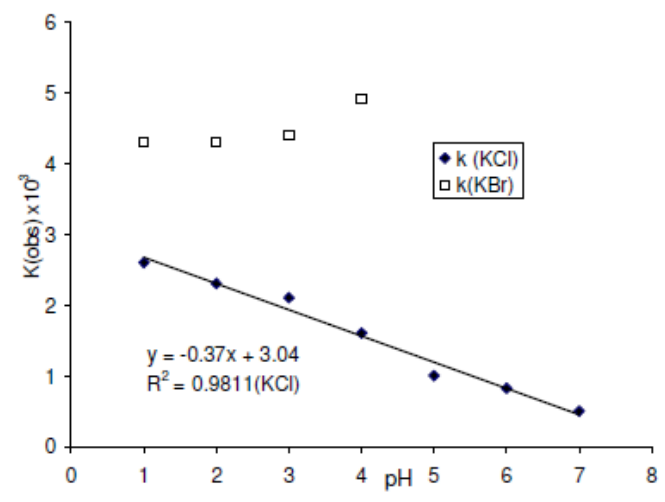

(b)

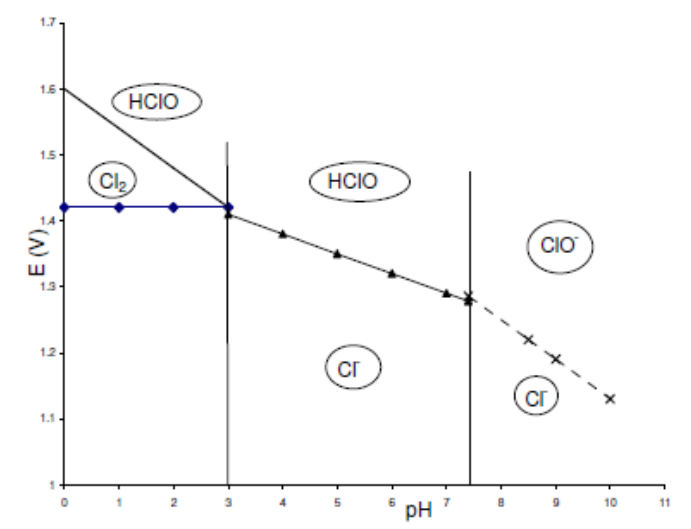

Figure 5a. Variation of the rate constant $\mathrm{K}(\mathrm{obs})$ in $\mathrm{mg} \mathrm{L}^{-1} \mathrm{~s}^{-1}$ as a function of $\mathrm{pH}$ (10 $\mathrm{mg} \mathrm{L}^{-1}$ of $\mathrm{MB}^{+}, 0.1 \mathrm{M} \mathrm{KCl}$ (or $\mathrm{KBr}$ ), $10 \mathrm{~mA}$, T: $293 \mathrm{~K}$ ). Figure 5b. E- pH diagram for chlorine systems [31].

The indirect oxidation of $\mathrm{MB}^{+}$in presence of $\mathrm{KBr}$ is efficient and fast as with $\mathrm{KCl}$ (Fig. 1b). The main differences between $\mathrm{KCl}$ and $\mathrm{KBr}$ are: i) the order with respect to $\mathrm{MB}^{+}$in presence of $\mathrm{KBr}$ is 2 instead zero (in presence of $\mathrm{KCl}$ ), ii) the rate constant $\mathrm{k}(\mathrm{obs})$ in presence of $\mathrm{KBr}$ remained constant for $\mathrm{pH}<4$ (Fig. 5a). As industrial wastewater contains already high amount of chloride, and the oxidation product in presence of $\mathrm{KBr}$ is similar to that in presence of $\mathrm{KCl}$, we focused our study in the last part on the oxidation of $\mathrm{MB}^{+}$in presence of $\mathrm{KCl}$.

\section{Effect of $p H$}

$\mathrm{pH}$ is one of the important factors that affect the performance of the electrochemical process. The effect of initial $\mathrm{pH}\left(\mathrm{pH}_{\mathrm{o}}\right)$ on the decolorization rate of $\mathrm{MB}^{+}$showed that the rate constant $\mathrm{k}(\mathrm{obs})$ increased linearly with decreasing in $\mathrm{pH}_{\mathrm{o}}$ for $\mathrm{pH}<7$ (Fig. 5a). Similar results are obtained during the degradation of azo dye [16] and reactive textile dyes [32]. The reason is due to the increase in $\mathrm{HClO} / \mathrm{Cl}_{2}$ amount in acidic medium, having the $\mathrm{HClO} / \mathrm{Cl}_{2}$ system higher standard potential than that of $\left(\mathrm{ClO}^{-} / \mathrm{Cl}^{-}\right)$(Fig. 5b). In basic medium $(7<\mathrm{pH}<9)$ the discoloration of $\mathrm{MB}^{+}$is slower than that in acidic medium. For higher $\mathrm{pH}$ $(\sim 12)$ the discoloration (much slower) is due to the nucleophilic attack of $\mathrm{OH}^{-}$.

\section{Effect of KCl concentration}

Several references confirmed that the concentration of the electrolyte had a pronounced effect on the cell performance [30, 32]. The effect of $\mathrm{KCl}$ concentration on the decolorization rate is undertaken. Linear relation is observed between $\mathrm{KCl}$ concentration and the rate constant (Fig. 6a). This result confirms the decolorization of the organic compounds via the generated chlorine compounds [29, 30].

\section{Effect of current intensity}

Current density is an important variable in electrochemical engineering. In this part, the indirect electro oxidation was done in acidic medium $\left(\mathrm{pH}_{\mathrm{o}}: 2\right)$ and in presence of $0.1 \mathrm{M} \mathrm{KCl}$, at several constant currents ranging from $1 \mathrm{~mA}$ to 20 
$\mathrm{mA}$. The results show that the decolorization rate or the oxidation rate of $\mathrm{MB}^{+}$ increase linearly with the increase in current (Fig. 6b). The linearity is also observed with other organic compounds [20, 28, 30]. The increase in rate constant with the applied current is mainly the increased production of active chlorine products at the anode [17, 29].

(a)

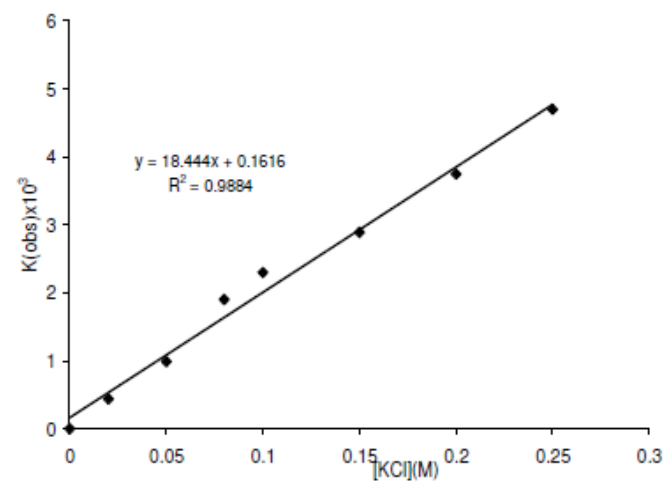

(b)

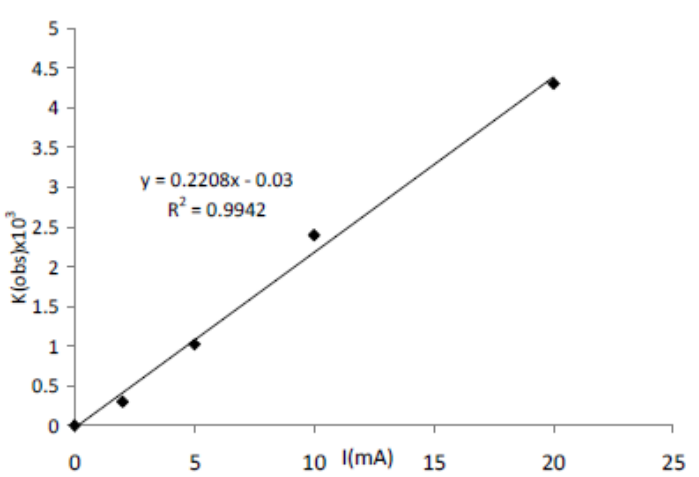

Figure 6a. Variation of the rate constant $\mathrm{K}(\mathrm{obs})$ in $\mathrm{mgL}^{-1} \mathrm{~s}^{-1}$ as a function of $\mathrm{KCl}$ concentration $\left(10 \mathrm{mg} \mathrm{L}^{-1}\right.$ of $\mathrm{MB}^{+}, \mathrm{pH}: 2,10 \mathrm{~mA}$, T: $\left.293 \mathrm{~K}\right)$. Figure $6 \mathbf{b}$. Variation of the rate constant $\mathrm{K}(\mathrm{obs})$ in $\mathrm{mg} \mathrm{L}^{-1} \mathrm{~s}^{-1}$ as a function of the current $\left(10\right.$ of $\mathrm{M} \mathrm{mg} \mathrm{L}^{-1} \mathrm{~B}^{+}, 0.1 \mathrm{M}$ $\mathrm{KCl}, \mathrm{pH}: 2, \mathrm{~T}: 293 \mathrm{~K})$.

\section{Effect of ionic force}

The effect of the ionic force on the oxidation of $\mathrm{MB}^{+}$was investigated by varying the concentration of $\mathrm{Na}_{2} \mathrm{SO}_{4}$ in the medium. The result showed that the rate constant of the reaction decreases with the increase in the ionic force (Fig. 7). This behavior can be explained by the decrease in chlorine solubility with the increase of salt concentration [18]. Similar result is also observed with the discoloration of $\mathrm{MB}^{+}$in presence of sulfite [25].

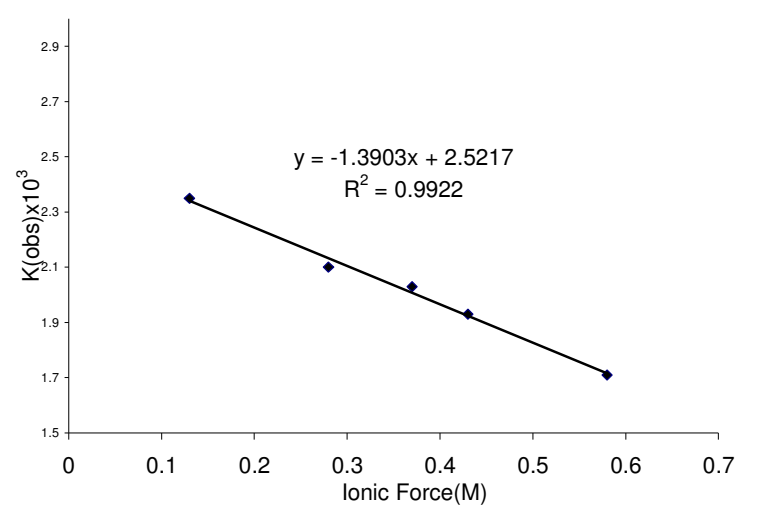

Figure 7. Variation of the rate constant $\mathrm{K}(\mathrm{obs})$ in $\mathrm{mg} \mathrm{L}^{-1} \mathrm{~s}^{-1}$ as a function of the ionic force $\left(10 \mathrm{mg} \mathrm{L}^{-1} \mathrm{MB}^{+}, 0.1 \mathrm{M} \mathrm{KCl}, 10 \mathrm{~mA}, \mathrm{pH}: 2\right.$ and $\left.293 \mathrm{~K}\right)$.

\section{Effect of temperature}

Table 1 presents the percent of color removal and the rate constant at different operating temperatures. It is clear that the variation of the rate of removal of 
color is negligible between 283 and $300 \mathrm{~K}$; however, the reaction temperature above $303 \mathrm{~K}$ showed a decrease in the rate of color removal. The same result is observed with other dyes $[20,22]$. The decrease in $\mathrm{Cl}_{2}(\mathrm{~g})$ solubility for $\mathrm{T}>303 \mathrm{~K}$ is the major reason for the decolorization decrease [18]. Another reason may be the mass transport controlled reduction of hypochlorite according to the following cathodic loss reaction [32]:

$$
\mathrm{HOCl}+\mathrm{H}^{+}+2 e \rightarrow \mathrm{Cl}^{-}+\mathrm{H}_{2} \mathrm{O}
$$

Table 1. Variation of the rate constant $\mathrm{k}(\mathrm{obs})$ and the $\%$ of color removal (after $400 \mathrm{~s}$ ) as a function of temperature $\left(10 \mathrm{mg} \mathrm{L}^{-1} \mathrm{MB}^{+}, 0.1 \mathrm{M} \mathrm{KCl}, 10 \mathrm{~mA}, \mathrm{pH}: 2\right)$.

\begin{tabular}{|l|l|l|l|l|l|l|l|}
\hline $\mathrm{T}(\mathrm{K})$ & 283 & 291.5 & 293 & 295 & 297 & 300 & 306 \\
\hline $\mathrm{K}(\mathrm{obs}) \times 10^{3}\left(\mathrm{mg} \mathrm{L}^{-1} \mathrm{~s}^{-1}\right)$ & 2.23 & 2.34 & 2.31 & 2.22 & 2.25 & 2.35 & 1.93 \\
\hline \% of color removal & 72.5 & 72.6 & 72.8 & 70 & 68 & 71 & $\underline{58}$ \\
\hline
\end{tabular}

\section{Conclusions}

The discoloration of $\mathrm{MB}^{+}$by electrochemical oxidation was affected by the operating conditions such as $\mathrm{pH}$, nature of strong electrolyte and many other parameters. The order with respect to $\mathrm{MB}^{+}$follows zero order in presence of chloride, but it is second order in presence of bromide. The efficiency of the electrochemical oxidation of $\mathrm{MB}^{+}$was proportional to chloride concentration and current density, but inversely proportional to the initial $\mathrm{pH}$ and ionic force. No significant effect of temperature and $\mathrm{MB}^{+}$concentration on the rate constant has been detected under the experimental conditions. No direct oxidation of $\mathrm{MB}^{+}$on Pt electrode in presence of $\mathrm{Na}_{2} \mathrm{SO}_{4}$ and $\mathrm{NaF}$. The oxidation of $\mathrm{MB}^{+}$by electro generated chlorine and bromine produced uncharged compound which probably corresponds to chlorinate or brominate methylene blue.

\section{Acknowledgment}

The authors wish to thank the "Ecole Doctorale de Sciences et Technologie" in Lebanese University for its help.

\section{References}

1. Parry RT. In: Parry RT editor. Principles and Applications of Modified Atmosphere Packaging of Foods. London. Blackie Academic Press: 1993.

2. http://en.wikipedia.org/wiki/Methylene blue

3. Robinson T, McMullan G, Marchant R, Nigam P. Bioresour Technol. 2001;77:247.

4. $\quad$ Ong S-T, Keng P-S, Lee W-N, Ha S-T, Hung Y-T. Water. 2011;3:157.

5. Katafias A, Kita P, Wrzeszcz G. Trans Metal Chem. 2006;32:31.

6. Pande S, Ghosh SK, Nath S, Praharaj S, Jana S, Panigrahi S, Basu S, Pal T. J Colloid Interface Sci. 2006;299:421. 
7. Pietkiewicz-Graczyk A, Impert O, Katafias A, Kita P. Polish J Chem. 2003;77:475.

8. Impert O, Katafias A, Kita P, Mills A, Pietkiewicz-Graczyk A, Wrzeszcz G. Dalton Trans. 2003:348.

9. Santos V, Morão A, Pacheco MJ, Ciríaco L, Lopes A. J Environ Eng Manage. 2008;18:193.

10. Martınez-Huitle CA, Ferro S. Chem Soc Rev. 2006;35:1324.

11. Peralta-Hernandez JM, Mejia S, Godinez LA, Meas-Vong Y. Environ Research. M. Palomar, editor. India: Research Signpost, Kerala; 2005.

12. Palma-Goyes RE, Guzmn-Duque FL, Peuela G, Gonzlez I, Nava JL, Torres-Palma RA. Chemosphere. 2010;81:26.

13. Polacro M, Palmas S, Renoldi F, Mascia M. J Appl Electrochem. 1999;29:147.

14. Wu M, Zhao G, Li M, Liu L, Li D. J Haz Mat. 2009;163:26.

15. Abu Ghalwaa NM, Abdel-Latif MS. J Iranian Chem Soc. 2005;2:238.

16. Alameddine I, El Jamal MM. J Univ Technol Metall (Sofia). 2009;44:127.

17. Panizza M, Barbucci A, Ricotti R, Cerisola G. Sep Purif Technol. 2007;54:382.

18. Schmittinger P. Chlorine. In: Ullmann's Encyclopaedia, vol. 6A. Weinheim: VCH; 1986. P. 399.

19. Donaldson JD, Grimes SM, Yasri NG, Wheals B, Parrickand J, Errington WE. J Chem Technol Biotechnol. 2002;77:756.

20. Raidan RI, Tabbara A, El Zant AA, El Jamal MM. J Univ Tech Metall (Sofia). 2009;44:79.

21. Peralta-Hernandez JM, Mendez-Tovar M, Guerra-Sanchez R, MartinezHuitle CA, Nava JL. Int J Electrochem. 2012:Article ID 154316.

22. Abu Ghalwa NM, Zaggout FR. J Environ Sci Health A. 2006;41:2271.

23. Korbahti BK, Tanyolac A. Water Res. 2003;37:1505.

24. Plater MJ. Arkivoc. 2003:37.

25. Mills A, Wang J. J Photochem Photobiol A. 1999;127:123.

26. Katafias A, Kita P, Wrzeszcz G. Trans Metal Chem. 2006;32:31.

27. Zaggout FR, Abu Ghalwa N. J Environ Manag. 2008;86:291.

28. Parsa JB, Abbasi M. Acta Chim Slov. 2007;54:792.

29. Zaviska F, Drogui P, Blais J-F, Mercier G. J Appl Electrochem. 39 (2009) 2397.

30. Maurice M, Desbarres J, Colin C, Jardy A, Bauer D. Chimie des solutions. Techniques et Documentation; 1990.

31. Kariyajjanavar P, Jogttappa N, Nayaka YA. J Haz Mat. 2011;190:952.

32. Rajkumar D, Kim JG. J Haz Mat. 2006;B136:203. 